THREE-YEAR FOLLOW-UP OF FLOWABLE BULK-FILL RESIN RESTORATIONS IN POSTERIOR TEETH: A DOUBLE-BLIND RANDOMIZED CONTROLLED CLINICAL TRIAL

\title{
Acompanhamento de três anos de restaurações do tipo bulk-fill flow em dentes posteriores: ensaio clínico controlado randomizado duplo-cego
}

Matheus Kury a,b, (ID Marcelo Goularta, (D) Thaís Thoméa, (D) Ewerton Nocchi Conceiçãoa, Fábio Hermann Coelho-de-Souza ${ }^{a}$, (D) Vanessa Cavallib , (D) Maria Carolina Guilherme Erhardt ${ }^{a}$

ABSTRACT

Objective: This randomized clinical trial evaluated the behavior of restorations with flowable bulk-fill resin composite in posterior teeth three years after the restorative treatment. Methods: Seventeen patients ( 12 women, 5 men, age 23-59) were selected to have at least two failing amalgam or resin restorations replaced and/ or to have a carious lesion restored. The cavities were randomly allocated to receive either the flowable bulk-fill composite Surefil SDR Flow occlusally covered with the conventional nano-hybrid composite Esthet-X HD (bulk and body technique) or filled exclusively with Esthet-X HD placed in $2 \mathrm{~mm}$ increments (incremental technique). A two-step etch-and-rinse adhesive was applied in all cavities. Thirty-four Class I or II restorations were performed in posterior teeth $(\mathrm{n}=17)$ during baseline. After 03 years, modified USPHS and FDI criteria were used to evaluate the restorations. Data were subjected to Mann-Whitney statistical analysis ( $\mathrm{p}<0.05)$. Results: At the 3-year follow-up, twenty-four restorations (17 Class I and 7 Class II) were evaluated. No differences were detected between the bulk and body and the incremental restorations ( $p>0.05)$. No restoration failures were observed over time. Conclusion: After 03 years of clinical service, all restorations using a flowable bulk-fill composite in posterior teeth showed an acceptable performance. Clinical significance: The overall quality of posterior restorations made with the bulk and body technique was similar to that of restorations made with a nano-hybrid composite incrementally placed.

* This study was registered in the National Clinical Trials Registry (REBEC - RBR-2g9st7).

Keywords: Follow-up studies. Clinical trial. Composite resins. Dental restoration, permanent. Surface properties.

\section{RESUMO}

Objetivo: Este ensaio clínico randomizado avaliou o comportamento de restaurações com resina composta bulk-fill flow em dentes posteriores após três anos do tratamento restaurador. Métodos: Dezessete pacientes (12 mulheres, 5 homens, idade 23-59) foram selecionados para ter pelo menos duas restaurações de amálgama ou de resina composta substituídas, ou receber tratamento restaurador para lesão cariosa. As cavidades foram aleatoriamente alocadas para receberem o compósito bulk-fill flow Suferil SDR Flow, oclusamente coberto por uma resina composta convencional nano-híbrida Esthet-X $H D$ (técnica bulk and body), ou serem preenchidas exclusivamente com Esthet- $X H D$, inseridas em incrementos de $2 \mathrm{~mm}$ cada (técnica incremental). Um adesivo convencional de dois passos foi aplicado em todas as cavidades. Trinta e quatro restaurações Classes I ou II foram realizados em dentes posteriores ( $\mathrm{n}=17)$ no início do estudo (baseline). Após 03 anos, os critérios do USPHS modificado e FDI foram utilizados para avaliar as restaurações. Os dados foram submetidos à análise estatística Mann-Whitney $(\mathrm{p}<0,05)$. Resultados: No acompanhamento de 3 anos, vinte e quatro restaurações (17 Classes I e 7 Classes II) foram avaliadas. Não foram detectadas diferenças entre as técnicas restauradoras ( $>>0,05)$. Não houve falha em nenhuma restauração ao longo do tempo. Conclusão: Após 03 anos de serviço clínico, todas restaurações utilizando um compósito bulk-fill flow em dentes posteriores demonstraram uma performance satisfatória. Significância clínica: A qualidade geral das restaurações em dentes posteriores realizadas com a técnica bulk and body foi similar ao das restaurações incrementais utilizando um compósito nano-híbrido.

* Este estudo foi registrado na plataforma de registro de ensaios clínicos brasileiros (REBEC - RBR-2g9st7).

Palavras-chave: Seguimentos. Ensaio clínico. Resinas compostas. Restauração dentária permanente. Propriedades de superfície.

\footnotetext{
a Operative Dentistry Division, School of Dentistry, Federal University of Rio Grande do Sul, Porto Alegre, RS, Brazil.

${ }^{\mathrm{b}}$ Restorative Dentistry Department, Piracicaba School of Dentistry, University of Campinas, Piracicaba, SP, Brazil.
}

Autor de correspondência: Matheus Kury - E-mail: matheuskury@hotmail.com

Data de envio: $26 / 06 / 2020$ | Data de aceite: 05/08/2020 


\section{INTRODUCTION}

Resin-based composites have been considered an effective option to overcome amalgam restorations drawbacks in the last decades. Although amalgam presents satisfactory mechanical properties, easy manipulation and placing, the necessity for more conservative and aesthetic restorations have stimulated adhesive procedures to be frequently performed in posterior teeth ${ }^{1,2}$. However, conventional composite resins still present certain limitations such as low depth of curing and the shrinkage stress - which may result in low degree of conversion, gap formation, postoperative sensitivity and secondary caries s,3-5. $^{1,}$

The incremental technique is indicated in order to enhance the conversion of conventional composite resins and to minimize the $\mathrm{C}$-factor of the cavity. As a result, chair time and technique sensitivity increases ${ }^{6}$. Therefore, bulk-fill composite resins are a feasible alternative to reduce clinical time and to optimize the technique ${ }^{7,8}$. Once bulk-fill composites are claimed to behave as "low-shrinkage resin", this type of material might be placed and light-cured in a single increment up to $5 \mathrm{~mm}$-thick ${ }^{5,9}$. For this purpose, some strategies have been used i.e. increase in the translucency, dual activation, new monomers and rheological modulators, new photoinitiators, sonic activation, and/or the use of glass fibers as filler content ${ }^{10}$. Particularly, the flowable bulk-fill composite Surefil SDR Flow ${ }^{\mathrm{TM}}$ (Dentsply) presents a new patented monomer, the so-called modified-UDMA, which provides a slower polymerization process and lower stress at the adhesive interface ${ }^{11,12}$. However, it is important to consider that restorations receiving flowable bulk-fill resin are required to be covered with a top layer with conventional paste-like resin (bulk and body technique) ${ }^{7}$.

Controversial results have been published concerning a range of mechanical properties of bulk-fill materials, but a micro-computed tomography assessment has already demonstrated that the volumetric shrinkage of bulk-fill resins decreased or remained stable after curing in comparison to conventional composites. The lowest post-gel shrinkage rates were found using SDR, whereas the highest rates were achieved using paste or flowable conventional composites $^{13}$. Some authors have also shown that the marginal integrity of the bulk-placed novel composites were as acceptable as the conventional ones ${ }^{12,13}$. In fact, a recent systematic review and meta-analysis demonstrated similar or better performance for bulk-fill composite resins (either flowable or paste-like) in comparison to the conventional ones in terms of polymerization stress, degree of conversion, cuspal deflection, fracture and flexural strength ${ }^{14}$.

Even though several in vitro evaluation of bulk-fill's mechanical properties are available, more clinical findings are necessary to justify the use of bulk-fill composite resins, specially the flowable ones, since there are few studies in the literature concerning their long-term performance in the oral cavity ${ }^{15,16}$. Therefore, the aim of this randomized study was to evaluate the clinical performance of posterior restorations performed with flowable bulk-fill composite resin in a 3-year recall. Restorations based on the insertion bulk increments of Surefil SDR Flow covered with a conventional resin (bulk and body technique) were compared to the ones performed only with a nano-hybrid composite (incremental technique). The null hypothesis tested was that no differences would be observed in the clinical performance of conventional and bulk-fill composites after 03 years of clinical service. 


\section{Material \& METHOds}

\section{Ethical aspects}

This study was approved by the Ethical Committee of the Federal University of Rio Grande do Sul. All patients were informed about the background of the study and agreed to be volunteers of the investigation by signing an informed consent form, which followed the CONSORT recommendations. This study was registered in the National Clinical Trials Registry (REBEC - RBR-2g9st7).

\section{Study design}

This is a double-blind 3-year follow-up of a randomized clinical trial with paired restorations placed in the oral cavity. Each patient received two treatments: while one restoration was performed applying bulk increment (up to $4 \mathrm{~mm}$ ) of flowable bulk-fill composite resin covered with a conventional nano-hybrid composite (bulk and body technique), the other one was incrementally placed only with the same conventional composite (incremental). The variable response assessed over time was the quality of the restorations according to modified USPHS and FDI criteria.

\section{Inclusion/exclusion criteria}

The patients were required to present a pair of class I or II failed restorations (amalgam/composite resin) with cusps partially involved and/or carious lesions on occlusal and/ or proximal surfaces. Teeth needed to be vital, as well as the participants were required to be free of edentulous spaces, important occlusal interferences, and parafunctional occlusion. The patients had to be over 18 years old and must not be assigned in any other clinical study.

Those patients allergic to the used materials, the ones presenting cracked teeth, periodontal disease, tooth sensitivity, antagonist teeth with porcelain restorations, or indirect restorations planned to be done, and those using chlorhexidine, were excluded from the clinical trial. The patients that were not able to attend the recalls and those presenting general health issues were also excluded from the study.

\section{Sample size and randomization}

The sample size calculation was performed using the statistical software G*Power. To establish differences in outcomes, theoretical sample size was set to 16,2 restorations per group when a 5\% significance level $(\alpha)$ and $80 \%$ power $(\beta)$ were applied. Therefore, seventeen patients were included in the present study. Twelve of them were women and five were men, with a mean age of 38 years old (ranging from 23 to 59). Thirty-four posterior teeth were randomly divided into two groups with paired restorations (bulk and body vs. incremental techniques).

The randomization was performed by a research assistant, who was not responsible for either the operative procedures or the evaluation process. This member assigned a code to each tooth to be restored. These codes were written in an opaque and sealed sheet, which were further randomly distributed among the two intervention groups (bulk and body / incremental). The participants were not aware in which cavity the experimental (bulk and body) and control restoration (incremental) were placed into. The materials were not seen 
by the patients. One single trained operator, which was a specialist, was responsible for the execution of all restorative procedures.

\section{Clinical procedures}

All restorative procedures were performed under rubber dam isolation. Water-cooled round diamond burs (\#1011, \#1012 or \#1014 - KG Sorensen, Cotia, São Paulo, Brazil) were used for removing existing restorations. Stainless steel burs were used for clearing away carious tissue. Etching with 35\% phosphoric acid (Dentsply, Milford, Delaware, USA) took $15 \mathrm{~s}$ in dentin and $30 \mathrm{~s}$ in enamel, and both surfaces were rinsed for $15 \mathrm{~s}$ with water and gently dried with an air blast in order to avoid dentin dehydration. A two-step total-etch adhesive (XP Bond - Dentsply DeTrey GmbH, Konstanz, Germany) was then applied following the manufacturer's instructions, and cured with a LED device (Optilight Max - Gnatus, Ribeirão Preto, São Paulo, Brazil) for 20 at a minimum of $800 \mathrm{mw} / \mathrm{cm}^{2}$. Class II cavities were performed using thin and circumferential metallic matrix bands and wooden wedges (TDV Dental, Pomerode, SC, Brazil). The type of the wedges used depended on the width of the interproximal contact of each patient.

The incremental restoration with Esthet-X HD (Dentsply, Milford, Delaware, USA) was placed ( $2 \mathrm{~mm}$-increments) using a spatula. Each increment was separately light cured, until the cavity was completely filled. The bulk and body restorations were initiated by the insertion of a Surefil SDR Flow (Dentsply, Milford, Delaware, USA) single increment up to $4 \mathrm{~mm}$, whose depth was checked using a millimeter probe. The flowable bulk-fill resin was inserted into the cavity by means of a specific syringe, and this increment was light-cured before any further step. Afterwards, the restoration was occlusally filled with the conventional composite (Esthet-X HD). Each increment of the covering layer was separately light cured for $20 \mathrm{~s}$.

After removal of the rubber dam, occlusion was checked with articulating paper (Angelus, Londrina, PR, Brazil) and adjusted, if necessary, with finishing diamond burs (KG Sorensen, Cotia, São Paulo, Brazil). Finishing was done using $\mathrm{Al}_{2} \mathrm{O}_{3}$ discs (Sof-Lex, 3M ESPE, St. Paul, Minnesota, USA), finishing strips (3M ESPE, St. Paul, Minnesota, USA) and finishing diamond burs (KG Sorensen, Cotia, São Paulo, Brazil). Finally, silicon polishers (Enhance - Dentsply, Milford, Delaware, USA) and nylon brush with silicon carbide particles (Kerr, Orange, California, USA) were used to polish the restorations. All adhesive materials are listed in Table 1. 
Table 1: Adhesive materials used in this study.

\begin{tabular}{|c|c|c|}
\hline Material & Composition & $\begin{array}{l}\text { Manufacturer, Batch number } \\
\text { and Exp. Date }\end{array}$ \\
\hline Phosporic Acid 37\% & $\begin{array}{l}\text { Phosphoric acid, highly dispersed silicon dioxide, deter- } \\
\text { gent, pigment, water }\end{array}$ & $\begin{array}{l}\text { Dentsply, Milford, Del- } \\
\text { aware, USA L492145D - } \\
\text { 05/2014 }\end{array}$ \\
\hline XP Bond & $\begin{array}{l}\text { Carboxylic acid modified dimethacrylate, phosphoric } \\
\text { acid modified acrylate resin, Urethane dimethacrylate, } \\
\text { triethyleneglycol dimethacrylate, 2-hydroxyethylmeth- } \\
\text { acrylate, butylated benzenediol (stabilizer), ethyl-4-di- } \\
\text { methylaminobenzoate, camphorquinone, function- } \\
\text { alised amorphous sílica, t-butanol }\end{array}$ & $\begin{array}{l}\text { Dentsply DeTrey GmbH, } \\
\text { Konstanz, Germany } \\
\text { 492145D-05/2014 }\end{array}$ \\
\hline Esthet-X HD & $\begin{array}{l}\text { Bisphenol A dimethacrylate, bisphenol A polyeth- } \\
\text { ylene glycol diether dimethacrylate, triethyleneglycol } \\
\text { dimethacrylate, barium-alumine-fluoro-borosilicate } \\
\text { glass, nanofiller silica. W: } 77 \% \text { V: } 60 \%\end{array}$ & $\begin{array}{l}\text { Dentsply, Milford, Dela- } \\
\text { ware, USA } \\
100726-07 / 2013\end{array}$ \\
\hline Surefil SDR Flow & $\begin{array}{l}\text { Urethane dimethacrylate resin, ethoxilated bisphenol-A } \\
\text { dimethacrylate, triethyleneglycol dimethacrylate, can- } \\
\text { phorquinine, uv stabilizer, butylated hydroxil toluene, } \\
\text { titanium oxide, iron oxid pigments, barium-alumi- } \\
\text { no-fluoro-silicate glass. W: } 68 \% \text { V: } 45 \%\end{array}$ & $\begin{array}{l}\text { Dentsply, Milford, Dela- } \\
\text { ware, USA } \\
\text { 091130-05/2012 }\end{array}$ \\
\hline
\end{tabular}

\section{Clinical evaluation}

One week after the procedures, both restorations (incremental and bulk and body) were clinically examined and bite-wings $\mathrm{x}$-rays were taken. FDI and modified USPHS criteria were used to qualitatively evaluate the restorations. Patients were recruited after 03 years for a clinical and radiographic follow-up by 2 calibrated raters. The raters were calibrated by assessing restorations in 5 volunteers who were not included in this study, being supervised by another professional with experience in using the present evaluation methods. When the raters did not agree with the scores, they discussed the most appropriate final outcome to be registered. The raters were blinded in regard to which group the restorations belonged to. An assistant was responsible to register the scores of each restoration corresponding to the code assigned in the randomization process.

Modified USPHS uses criteria such as marginal adaptation, anatomic form and marginal discoloration using Alpha, Bravo and Charlie scores (Table 2). FDI assess aesthetic, functional and biological properties adopting the following scores: 1) clinically excellent/ very good, 2) clinically good, 3) clinically sufficient/satisfactory, 4) clinically unsatisfactory, 5) clinically poor (Table 3 ). 
Table 2: Modified USPHS criteria.

\begin{tabular}{llll}
\hline Criteria & Alfa (A) & Bravo (B) & Charlie (C) \\
\hline Marginal adaptation & $\begin{array}{l}\text { No evidence of marginal gap } \\
\text { in which the explorer does } \\
\text { not catch }\end{array}$ & $\begin{array}{l}\text { Evidence of visible marginal } \\
\text { gap with no dentin exposure }\end{array}$ & $\begin{array}{l}\text { Evidence of visible marginal } \\
\text { gap with dentin exposure }\end{array}$ \\
\hline Anatomic form & $\begin{array}{l}\text { Restoration is contiguous } \\
\text { with tooth anatomy }\end{array}$ & $\begin{array}{l}\text { Restoration discontinuous } \\
\text { with tooth anatomy but the } \\
\text { loss of material is not suffi- } \\
\text { cient to expose dentin }\end{array}$ & $\begin{array}{l}\text { Restoration discontinuous } \\
\text { with tooth anatomy and the } \\
\text { loss of material is sufficient to } \\
\text { expose dentin }\end{array}$ \\
\hline Marginal discoloration & No penetration of staining at & $\begin{array}{l}\text { Little pigmentation that is } \\
\text { removed after polishing }\end{array}$ & $\begin{array}{l}\text { Discoloration that pene- } \\
\text { trates the margin and is not } \\
\text { removed after polishing }\end{array}$ \\
\hline Sensitivity to thermal stimulus & Absent & Present & - \\
\hline Sensitivity to chewing & Absent & Present & - \\
\hline Secondary caries & No evidence of caries at the & Evidence of caries at the & - \\
& margin & margin & \\
\hline Pulp sensitivity test & Presence of sensitivity to cold & Absence of sensitivity to cold & - \\
\hline
\end{tabular}

Table 3: FDI Criteria for aesthetic, functional and biological properties.

\begin{tabular}{|c|c|c|c|c|c|}
\hline Aesthetic Properties & Score 1 & Score 2 & Score 3 & Score 4 & Score 5 \\
\hline Surface Luster & $\begin{array}{l}\text { Surface gloss com- } \\
\text { parable surround- } \\
\text { ing tooth tissues }\end{array}$ & $\begin{array}{l}\text { Surface slightly } \\
\text { dull but not notice- } \\
\text { able in speaking } \\
\text { distance }\end{array}$ & $\begin{array}{l}\text { Dull but still ac- } \\
\text { ceptable if covered } \\
\text { with adhesive or } \\
\text { saliva }\end{array}$ & $\begin{array}{l}\text { Polishing not able } \\
\text { to mask roughness. } \\
\text { Finishing is neces- } \\
\text { sary and possible }\end{array}$ & $\begin{array}{l}\text { Unacceptably } \\
\text { rough. Improve- } \\
\text { ment by finishing } \\
\text { is not feasible }\end{array}$ \\
\hline Surface Staining & $\begin{array}{l}\text { No marginal or } \\
\text { surface staining }\end{array}$ & $\begin{array}{l}\text { Minor marginal } \\
\text { staining and/or } \\
\text { mild surface stain- } \\
\text { ing present }\end{array}$ & $\begin{array}{l}\text { Moderate surface } \\
\text { staining not notice- } \\
\text { able in speaking } \\
\text { distance }\end{array}$ & $\begin{array}{l}\text { Staining noticeable } \\
\text { in speaking dis- } \\
\text { tance. Restoration's } \\
\text { correction }\end{array}$ & $\begin{array}{l}\text { Staining is totally } \\
\text { unacceptable. } \\
\text { Restoration needs } \\
\text { to be replaced }\end{array}$ \\
\hline $\begin{array}{l}\text { Color Match/Trans- } \\
\text { lucency }\end{array}$ & $\begin{array}{l}\text { Excellent match } \\
\text { with surrounding } \\
\text { enamel }\end{array}$ & $\begin{array}{l}\text { Acceptable but } \\
\text { minor deviations in } \\
\text { shade in compari- } \\
\text { son to tooth }\end{array}$ & $\begin{array}{l}\text { Clear deviation in } \\
\text { color match not } \\
\text { affecting aesthetics }\end{array}$ & $\begin{array}{l}\text { Clinically unsat- } \\
\text { isfactory. Partial } \\
\text { removal and repair } \\
\text { is possible }\end{array}$ & $\begin{array}{l}\text { Clinically unsatis- } \\
\text { factory. Replace- } \\
\text { ment is required }\end{array}$ \\
\hline $\begin{array}{l}\text { Aesthetic Anatomic } \\
\text { Form }\end{array}$ & Ideal form & $\begin{array}{l}\text { Form is slightly } \\
\text { deviated from the } \\
\text { remainder of the } \\
\text { tooth }\end{array}$ & $\begin{array}{l}\text { Form distinct from } \\
\text { homologous tooth } \\
\text { but it is optical } \\
\text { acceptable }\end{array}$ & $\begin{array}{l}\text { Form is altered, } \\
\text { the esthetic is } \\
\text { unacceptable. Cor- } \\
\text { rection is necessary }\end{array}$ & $\begin{array}{l}\text { Form is unsatisfac- } \\
\text { tory. Replacement } \\
\text { is required }\end{array}$ \\
\hline Functional Properties & Score 1 & Score 2 & Score 3 & Score 4 & Score 5 \\
\hline $\begin{array}{l}\text { Material fracture/ } \\
\text { retention }\end{array}$ & $\begin{array}{l}\text { Restoration } \\
\text { without fractures } \\
\text { or cracks }\end{array}$ & $\begin{array}{l}\text { Small hairline crack } \\
\text { is visible }\end{array}$ & $\begin{array}{l}\text { Several hairline } \\
\text { cracks present/ } \\
\text { limited chipping of } \\
\text { material }\end{array}$ & $\begin{array}{l}\text { Proximal contacts } \\
\text { fractured and } \\
\text { without partial loss } \\
\text { of }<\text { than half of } \\
\text { restoration }\end{array}$ & $\begin{array}{l}\text { Loss of resto- } \\
\text { rations/bulk } \\
\text { fracture with gap > } \\
250 \mu \mathrm{m} \text { with partial } \\
\text { loss }\end{array}$ \\
\hline Marginal adaptation & $\begin{array}{l}\text { Harmonious } \\
\text { continuation of the } \\
\text { margin outline }\end{array}$ & $\begin{array}{l}\text { Integrity is not } \\
\text { ideal, but could } \\
\text { be upgraded by } \\
\text { polishing }\end{array}$ & $\begin{array}{l}\text { Leakage/discol- } \\
\text { oration is present } \\
\text { but limited to the } \\
\text { border area }\end{array}$ & $\begin{array}{l}\text { Localized gap } \\
>250 \mu m \text { may } \\
\text { result in dentine } \\
\text { exposure. Repair is } \\
\text { necessary }\end{array}$ & $\begin{array}{l}\text { Generalized gap } \\
\text { > than } 250 \mu \mathrm{m} . \\
\text { Replacement } \\
\text { necessary }\end{array}$ \\
\hline
\end{tabular}




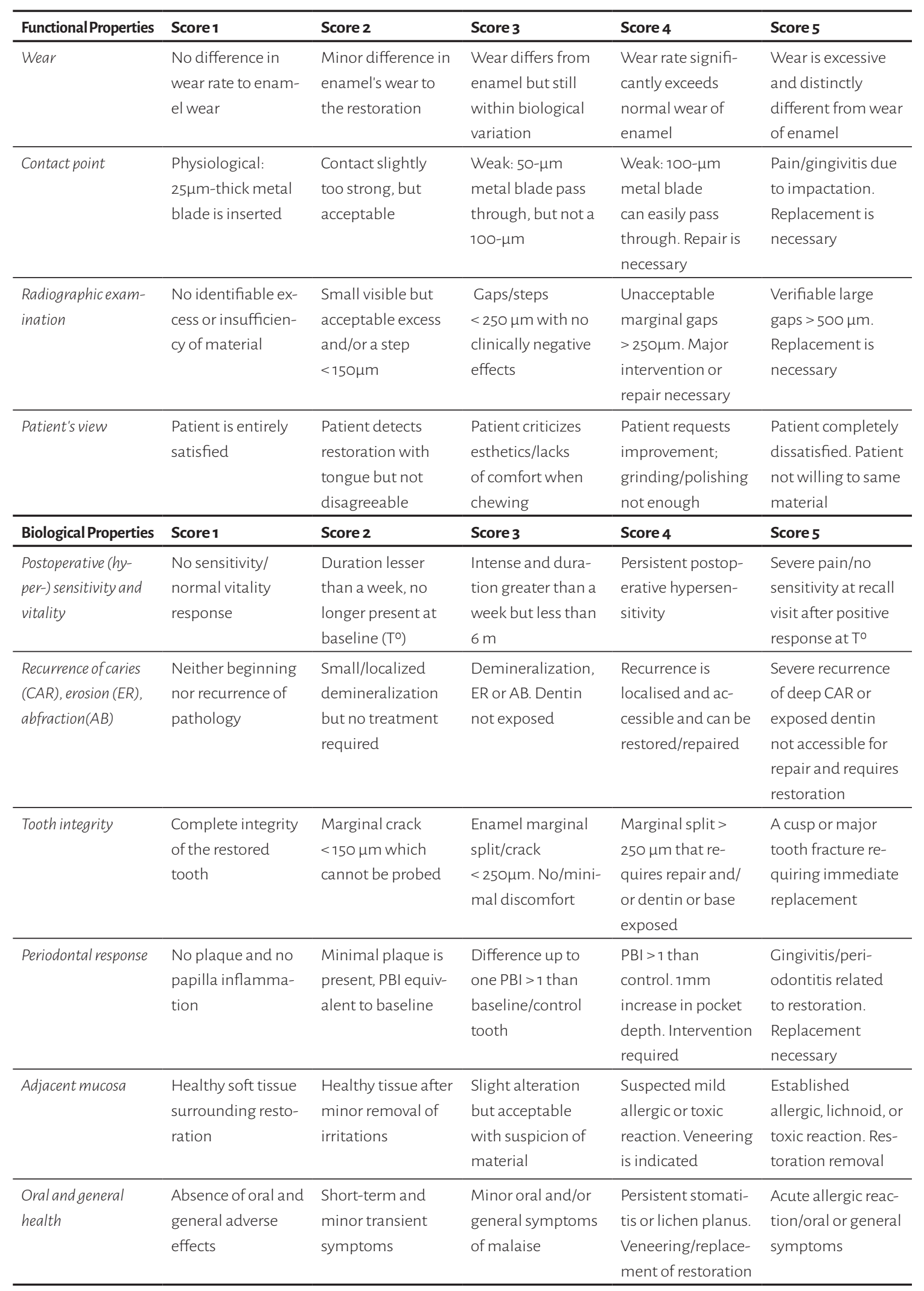




\section{Statistical analysis}

Non-parametric Mann-Whitney test with a significance level of 5\% was used to evaluate the data collected from the clinical assessment at the third-year recall. Data were analyzed with SSPS Inc. (PASW Statistics for Windows, Version 18.0. Chicago: SPSS Inc).

\section{Results}

After three years, 12 patients attended the recalls (Figure 1). Twenty-four restorations were evaluated after 03 years in clinical service. It was observed that seventeen restorations were Class I, while seven were Class II. The majority of the evaluated restorations were placed in molar ( $M$ ), in comparison to premolar (PM) teeth (Table 4). None of the restoration failed, and postoperative sensitivity on the evaluated teeth was not reported during this interval whatsoever.

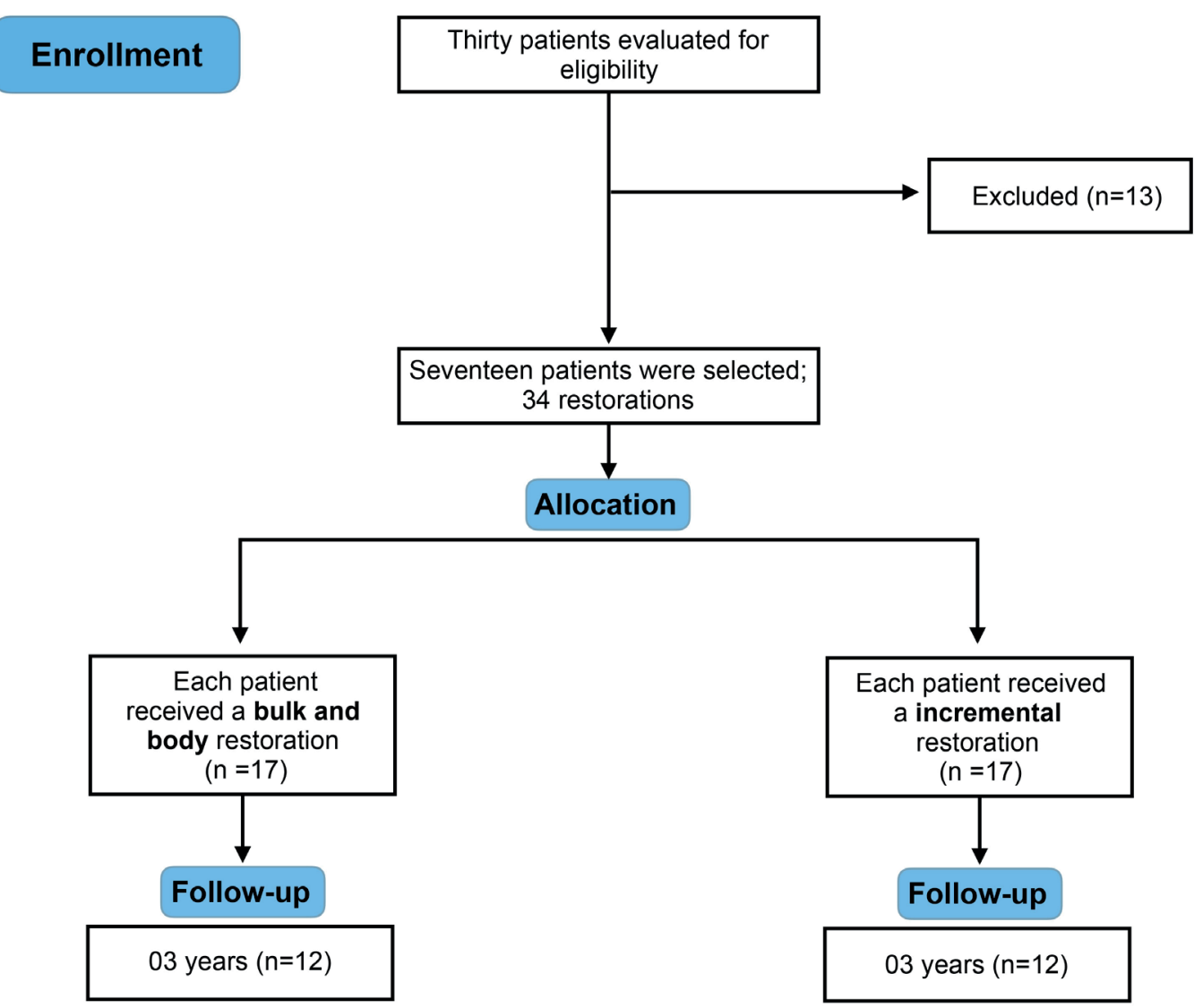

Figure 1: Flow chart of the volunteers during the present clinical trial study. 
Table 4: Tooth and cavity distributions in the third-year clinical follow-up.

\begin{tabular}{lll}
\hline Tooth/Cavity Type & Bulk and Body $(\mathbf{n})$ & Incremental $(\mathbf{n})$ \\
\hline Molar & 7 & 9 \\
\hline Premolar & 5 & 3 \\
\hline Total & 12 & 12 \\
\hline Class I & 9 & 8 \\
\hline Class II & 3 & 4 \\
\hline Total & $\mathbf{1 2}$ & $\mathbf{1 2}$ \\
\hline
\end{tabular}

No significant differences between the types of restorative techniques (bulk and body or incremental) were detected within each of the modified USPHS criteria (Table 5). Marginal discoloration was the main divergence contrast between the types of restorations. Bulk and body restorations presented more Bravo scores (33\%) for such criterion (2 Bravo scores were observed in molar teeth and Class II restorations, 1 Bravo score was seen in PM and Class I restoration), but this was not statistically different from incremental restoration $(p=.30)$ All restorations were clinically satisfactory.

Table 5: Mann-Whitney test for modified USPHS criteria in bulk-fill and conventional resin composites restorations.

\begin{tabular}{llllll}
\hline Criteria & $\begin{array}{l}\text { Bulk and Body } \\
\mathbf{n}(\mathbf{A} / \mathbf{B} / \mathbf{C})\end{array}$ & $\begin{array}{l}\text { Clinical } \\
\text { acceptance }\end{array}$ & $\begin{array}{l}\text { Incremental } \\
\mathbf{n}(\mathbf{A} / \mathbf{B} / \mathbf{C})\end{array}$ & $\begin{array}{l}\text { Clinical } \\
\text { acceptance }\end{array}$ & $\mathbf{p}$ \\
\hline Marginal adaptation & $12(11 / 1 / 0)$ & $100 \%$ & $12(11 / 1 / 0)$ & $100 \%$ & 1.0 \\
\hline Anatomic form & $12(11 / 1 / 0)$ & $100 \%$ & $12(10 / 2 / 0)$ & $100 \%$ & 0.75 \\
\hline Marginal discoloration & $12(8 / 4 / 0)$ & $100 \%$ & $12(11 / 1 / 0)$ & $100 \%$ & 0.30 \\
\hline Sensitivity to thermal stimulus & $12(12 / 0 / 0)$ & $100 \%$ & $12(12 / 0 / 0)$ & $100 \%$ & 1.0 \\
\hline Sensitivity to chewing & $12(12 / 0 / 0)$ & $100 \%$ & $12(12 / 0 / 0)$ & $100 \%$ & 1.0 \\
\hline Secondarycaries & $12(12 / 0 / 0)$ & $100 \%$ & $12(12 / 0 / 0)$ & $100 \%$ & 1.0 \\
\hline Pulpsensitivity test & $12(12 / 0 / 0)$ & $100 \%$ & $12(12 / 0 / 0)$ & $100 \%$ & 1.0 \\
\hline
\end{tabular}

Likewise, the restorations presented no statistically significant difference under FDI evaluation (Table 6). Color match and translucency showed a considerable number of "clinically good" scores for bulk and body and incremental groups, accounting for 53\% and 50\%, respectively. While the bulk and body group showed a higher prevalence of these scores in molar teeth, the "clinically good" score was equally found in $M$ or PM teeth $(n=3)$ for incremental restorations. Regarding this criterion, restorations using bulk and body technique only were marked with less excellent scores for surface staining. Overall, all restorations in both groups behaved clinically acceptable in the third-year recall. 
Table 6: Mann-Whitney test for aesthetic, functional and biological properties of FDI criteria in bulk-fill and conventional resin composites restorations.

\begin{tabular}{|c|c|c|c|c|c|}
\hline Aesthetic properties & $\begin{array}{l}\text { Bulk and Body } \\
\text { n (1/2/3/4/5) }\end{array}$ & $\begin{array}{l}\text { Clinical } \\
\text { acceptance }\end{array}$ & $\begin{array}{l}\text { Incremental } \\
n(1 / 2 / 3 / 4 / 5)\end{array}$ & $\begin{array}{l}\text { Clinical } \\
\text { acceptance }\end{array}$ & $\mathbf{p}$ \\
\hline Surface lustre & $12(12 / 0 / 0 / 0 / 0)$ & $100 \%$ & $12(11 / 1 / 0 / 0 / 0)$ & $100 \%$ & 0.75 \\
\hline Surface staining & $12(9 / 2 / 1 / 0 / 0)$ & $100 \%$ & $12(11 / 0 / 1 / 0 / 0)$ & $100 \%$ & 0.52 \\
\hline Color match and translucency & $12(5 / 7 / 0 / 0 / 0)$ & $100 \%$ & $12(6 / 6 / 0 / 0 / 0)$ & $100 \%$ & 0.48 \\
\hline Aesthetic anatomical form & $12(12 / 0 / 0 / 0 / 0)$ & $100 \%$ & $12(12 / 0 / 0 / 0 / 0)$ & $100 \%$ & 1.0 \\
\hline Functional properties & $\begin{array}{l}\text { Bulk and Body } \\
\text { n (1/2/3/4/5) }\end{array}$ & $\begin{array}{l}\text { Clinical } \\
\text { acceptance }\end{array}$ & $\begin{array}{l}\text { Incremental } \\
n(1 / 2 / 3 / 4 / 5)\end{array}$ & $\begin{array}{l}\text { Clinical } \\
\text { acceptance }\end{array}$ & $\mathbf{p}$ \\
\hline Fracture of material and retention & 12 (12/0/0/0/0) & $100 \%$ & $12(12 / 0 / 0 / 0 / 0)$ & $100 \%$ & 1.0 \\
\hline Marginal adaptation & $12(12 / 0 / 0 / 0 / 0)$ & $100 \%$ & $12(12 / 0 / 0 / 0 / 0)$ & $100 \%$ & 1.0 \\
\hline Wear & $12(12 / 0 / 0 / 0 / 0)$ & $100 \%$ & 12 (12/0/0/0/0) & $100 \%$ & 1.0 \\
\hline Contact point & $12(11 / 0 / 1 / 00)$ & $100 \%$ & $12(11 / 0 / 1 / 0 / 0)$ & $100 \%$ & 1.0 \\
\hline Radiographic examination & $12(12 / 0 / 0 / 0 / 0)$ & $100 \%$ & 12 (12/0/0/0/0) & $100 \%$ & 1.0 \\
\hline Patient's view & $12(12 / 0 / 0 / 0 / 0)$ & $100 \%$ & $12(12 / 0 / 0 / 0 / 0)$ & $100 \%$ & 1.0 \\
\hline Biological properties & $\begin{array}{l}\text { Bulk and Body } \\
\text { n (1/2/3/4/5) }\end{array}$ & $\begin{array}{l}\text { Clinical } \\
\text { acceptance }\end{array}$ & $\begin{array}{l}\text { Incremental } \\
n(1 / 2 / 3 / 4 / 5)\end{array}$ & $\begin{array}{l}\text { Clinical } \\
\text { acceptance }\end{array}$ & $\mathbf{p}$ \\
\hline Postoperative sensitivity and tooth vitality & $12(12 / 0 / 0 / 0 / 0)$ & $100 \%$ & $12(12 / 0 / 0 / 0 / 0)$ & $100 \%$ & 1.0 \\
\hline Recurrence of caries, erosion and abfraction & $12(12 / 0 / 0 / 0 / 0)$ & $100 \%$ & $12(12 / 0 / 0 / 0 / 0)$ & $100 \%$ & 1.0 \\
\hline Tooth integrity & $12(12 / 0 / 0 / 0 / 0)$ & $100 \%$ & $12(12 / 0 / 0 / 0 / 0)$ & $100 \%$ & 1.0 \\
\hline Periodontal response & $12(12 / 0 / 0 / 00)$ & $100 \%$ & $12(12 / 0 / 0 / 0 / 0)$ & $100 \%$ & 1.0 \\
\hline Adjacent mucosa & 12 (12/0/O/০/0) & $100 \%$ & 12 (12/o/o/O/O) & $100 \%$ & 1.0 \\
\hline Oral and general health & 12 (12/o/o/o/O) & $100 \%$ & 12 (12/o/o/o/O) & $100 \%$ & 1.0 \\
\hline
\end{tabular}

\section{Discussion}

The present study was designed to answer if restoring posterior teeth with either bulk and body or incremental techniques would result in differences regarding their clinical performance over time. The three-year follow-up showed that all restorations placed using bulk-fill composites in posterior teeth were clinically acceptable. Also, no statistical differences between both techniques regarding both modified USPHS and FDI criteria were detected. Therefore, the null hypothesis was accepted.

Even though the main divergence between the types of restorations for modified USPHS was the marginal discoloration criterion, bulk and body restorations outcomes were satisfactory three years after the restorative procedures. For FDI criteria, color match and translucency was the most evident criterion that did not present clinical excellence. However, both groups presented similar results. Although the highest scores were not detected in some of the criteria, all restorations were considered clinically effective. Additionally, no secondary caries was observed after 03 years of follow-up. According to Ásvaldsdóttir et al. ${ }^{17}$, secondary caries often occurs after 03 years or later, reinforcing the importance of an appropriate follow-up.

Lower scores for color match and translucency may be explained by the fact that most of the procedures replaced failing amalgam restorations, which maintained the discolored dentin as a conservative approach. By the time restorations of the present study were placed, there had not been released samples of bulk-fill composite resin with different 
chromas that could mask dark-stained dentin. Therefore, the material was available only in one semi-translucent universal shade. Nevertheless, it is important to emphasize that all procedures took place in a non-aesthetic area and, more importantly, the color issue did not affect the functional and biological aspects of the restoration, presenting no secondary caries and postoperative sensitivity whatsoever. At the present moment, SDR is available in universal as well as in A1, A2 and A3 chromas, which may probably overcome this limitation ${ }^{18}$.

Translucency is believed to allow the bulk-fill system to be cured up to a $5 \mathrm{~mm}$ depth ${ }^{19}$. This optical feature is based not only on the scattering and absorption coefficients of the composite, but also on the filler particles ${ }^{20}$. According to Ilie et al. ${ }^{21}$, the translucency parameter of SDR is believed to be high probably because of its large filler size. ${ }^{21}$ Additionally, it has been proven by means of Vickers microhardness tests that bulk-fill composites can be light-cured up to the depth claimed by the manufacturers, which could assure that deep areas of the restorations is being effectively cured ${ }^{22}$.

Regarding marginal adaptation, Furness et al. ${ }^{23}$ compared the internal marginal adaptation when conventional or bulk-fill resin composites were used. For conventional composites, it has been found that a gap-free margin was more detectable in axial rather than in pulpal surfaces. On the other hand, SDR presented no differences among the observed marginal locations, showing a better overall gap-free performance in comparison to the other types of bulk-fill composite resins ${ }^{23}$. Interestingly, the choice for a total-etch system in the present study was based on studies that investigated the quality of marginal integrity restorations ${ }^{23}$. Interfaces of restorations with SDR applied over a total-etch adhesive produced less gaps than over a self-etch adhesive. The same pattern was observed when internal adaptation was evaluated ${ }^{24}$.

Marginal adaptation satisfactory results after three years could be justified by the low polymerization stress of the tested composites. Rosatto et al ${ }^{25}$ measured the post-gel shrinkage of bulk-fill and conventional resin composites through the strain gauge technique. SDR presented the lowest shrinkage curve for 5 minutes after light-curing, while conventional composite presented the highest curve ${ }^{25}$. This might be explained by the absence of Bis-GMA, the presence of TEGDMA and the modified-UDMA ${ }^{18}$. Despite the high molecular weight of the modified-UDMA, it is believed that this molecule does not present hydroxyl groups in its composition, which reduces intermolecular interactions and facilitates monomer conversion. It also reduces viscosity as well improves the reactivity of the monomers, even in late stages of the polymerization ${ }^{13}$.

On the contrary, Leprince et al. ${ }^{26}$ revealed that SDR provided lower values for elastic modulus, flexural strength, and Vickers microhardness than the conventional composite Grandio (Voco, Cuxhaven, Germany) ${ }^{26}$. The authors suggested that the use of bulk-fill composites for fillings under occlusal loading may be questionable. Also, it was stated that flowable bulk-fill resin composites diminished properties values in comparison to conventional resin composites due to differences in filler content. Nonetheless, for a more comprehensive mechanical evaluation of the flowable bulk-fill resin composites, it must be considered that a conventional composite covering layer is mandatory, playing an important role in the mechanical performance of the restoration. This covering layer, on the other hand, is not necessary in restorations performed with paste-like bulk-fill resin composites, since their elastic modulus was similar to conventional composite resins ${ }^{26}$.

As a result of the mechanical characteristics of "low-shrinkage" resin composite, the main clinical advantage is the decrease in the postoperative sensitivity ${ }^{23,27}$. This symptom was absent in the patients restored with bulk-filled restorations (bulk and body technique), corroborating with another clinical trial evaluating the same flowable bulk-fill material after 06 years of clinical service ${ }^{28}$. Indeed, van Djiken \& Pallesen ${ }^{29}$ demonstrated that $93.9 \%$ of bulk and body restorations were successful during the 6 -year follow-up ${ }^{29}$. It is important to note 
that their study ${ }^{29}$ represents the longest clinical evaluation of restorations performed using a flowable bulk-fill resin (SDR), showing that this technology presented highly acceptable results even after 6 years elapsed from the restorative procedure. The main reason for the failure in van Djiken's study was partial fractures in Class II restorations, which was detected only in bruxing-risk volunteers ${ }^{29}$. In fact, the majority of the restoration performed in their clinical trial was Class II, the opposite to our study. As Class I restorations are less likely to fail than Class II, ${ }^{30}$ this condition could have influenced the results of the present follow-up evaluation. A previous study reported that an additional restored surface increased $40 \%$ the risk of failure ${ }^{31}$. Therefore, the $100 \%$ clinical acceptance of the restorations after 03 years herein reported could have been positively affected by the type of restorations.

Interestingly, a recent prospective clinical trial while comparing restorations with different types of flowable bulk-fill composites showed that, contrarily to Filtek Bulk Fill Flow, restorations with SDR decreased the cold sensitivity after one year ${ }^{32}$. As it is widely known, the sensitivity occurs due to gap formation, which, in turn, may be an outcome of the composite shrinkage stress overcoming the bond strength ${ }^{33}$. Thus, it may be suggested that the higher SDR's degree of conversion could have contributed to this scenario. Also, it is important to take into account that Filtek Bulk Fill Flow presents monomers similar to conventional composite resins ${ }^{12}$. The main difference of SDR in comparison to the other bulk-fill resin composites is the composition of its organic matrix. The new patented monomer, called modified-UDMA, enables a slower polymerization process. Therefore, lower stress at the adhesive interface is expected ${ }^{11,12}$. Such technology is considered a "stress modulator", and it is known that a slower curing process allows an improved dissipation of strength within the cavity 5 .

Clinical trials and/or in vivo studies may be the most appropriate alternative to answer questions regarding new dental techniques ${ }^{34}$. Some recent randomized clinical trials showed that restorations with paste-like bulk-fill composite resins also presented satisfactory results over time ${ }^{35,36}$. In terms of clinical procedures, caution with the light-curing unit is extremely important, since evidences showed that stable irradiance, homogeneity of light beam and wavelength components may influence the degree of conversion, depth of cure and wear of bulk-fill composite resins depending on the type and brand of each bulk-fill material ${ }^{37-40}$.

Indeed, a disadvantage of restoring posterior teeth with bulk-fill composite resin could be that the susceptibility to variance in the irradiance of the light-curing units was shown to be material dependent ${ }^{21}$. Also, a higher amount of composite being cured at the same time, in comparison to the incremental technique, could result in increased heat generation ${ }^{41}$. Further in vivo analysis on the effect of the increase of bulk-fill composite's temperature are paramount to determine its effect on the human pulp tissue ${ }^{5}$. Interestingly, it should be addressed that materials are not the only factor that may influence restorations longevity: cavity extension, number of involved surfaces, tooth position and number of patient's restorations are also aspects that markedly determine long-term quality of composite restorations ${ }^{30}$.

One limitation of the present study was the drop-out of the patients after 03 years $(n=5)$. The main reason for this outcome was the fact that the volunteers $(n=4)$ moved to other cities. The Research crew was not able to reach one patient by none of the following methods: telephone calls, e-mails and letters. Even though the follow-up evaluation of all the volunteers could have detected some difference between the intervention groups, the present results showed that the performance of the assessed restorations using the bulk and body technique was satisfactory (100\% of clinical efficacy) after 03 years of clinical service. Another limitation of the present clinical trial would be that the baseline values were not included in this report. Nevertheless, the scores of both evaluation methods were maximum (either Alfa for USPHS or 1 for FDI) after one week of restoration procedures, and no failure was detected up to third year of clinical follow-up. However, continuous evaluation over 
time appears as an indispensable step to consolidate the bulk-fill composite as an effective and safe material to be used for restoration of posterior teeth.

\section{CONCLUSION}

Posterior restorations using a flowable bulk-fill composite (bulk and body technique) showed similar clinical performance when compared to an incremental nano-hybrid resin composite incrementally placed after 03 years of clinical service. Both restorative methods were $100 \%$ clinically acceptable and there was no failure in any of the groups.

\section{REFERENCES}

1. Mazer RB, Leinfelder KF, Russell CM. Degradation of microfilled posterior composite. Dent Mater. 1992;8(3):185-9. doi:10.1016/0109-5641(92)90080-v.

2. Opdam NJM, Bronkhorst EM, Roeters ]M, Loomans BAC. A retrospective clinical study on longevity of posterior composite and amalgam restorations. Dent Mater. 2007;23(1):2-8.

3. Frauscher KE, Ilie N. Degree of conversion of nano-hybrid resin-based composites with novel and conventional matrix formulation. Clin Oral Investig. 2013;17(2):635 42. doi:10.1007/s00784-012-0736-y.

4. Nassar HM, González-Cabezas C. Effect of gap geometry on secondary caries wall lesion development. Caries Res. 2011;45(4):346-52.

5. Pfeifer CS. Polymer-based direct filling materials. Dent Clin North Am. 2017;61(4):733 50. doi:10.1016/j. cden.2017.06.002.

6. Fronza BM, Abuna GF, Braga RR, Rueggeberg FA, Giannini M. Effect of Composite Polymerization Stress and Placement Technique on Dentin Micropermeability of Class I Restorations. J Adhes Dent. 2018;20(4):355 63. doi:10.3290/j.jad.a40987.

7. Sebold M, Lins RBE, André CB, Martins LRM, Giannini M. Flowable and Regular Bulk-Fill Composites: A Comprehensive Report on Restorative Treatment. Int ] Periodontics Restorative Dent. 2020;40(2):293 300. doi:10.11607/ prd.3932.

8. Campos EA, Ardu S, Lefever D, Jassé FF, Bortolotto T, Krejci I. Marginal adaptation of class II cavities restored with bulk-fill composites. J Dent. 2014;42(5):575 81. doi:10.1016/j.jdent.2014.02.007.

9. Zorzin J, Maier E, Harre S, Fey T, Beli R, Lohbauer U, et al. Bulk-fill resin composites: polymerization properties and extended light curing. Dent Mater. 2015;31(3):293 301. doi:10.1016/j.dental.2014.12.010.

10. Van Ende A, De Munck], Lise DP, Van Meerbeek B. Bulk-Fill Composites: a review of the current literature.] Adhes Dent. 2017;19(2):95109. doi:10.3290/j.jad.a38141.

11. Benetti AR, Havndrup-Pedersen C, Honoré D, Pedersen MK, Pallesen U. Bulk-fill resin composites: polymerization contraction, depth of cure, and gap formation. Oper Dent. 2015;40(2):190 200. doi:10.2341/13-324-L.

12. Alshali RZ, Salim NA, Sung R, Satterthwaite JD, Silikas N. Qualitative and quantitative characterization of monomers of uncured bulk-fill and conventional resin-composites using liquid chromatography/mass spectrometry. Dent Mater. 2015;31(6):711-20.

13. Ilie N, Hickel R. Investigations on a methacrylate-based flowable composite based on the SDR??? technology. Dent Mater. 2011;27(4):348-55.

12. Heintze SD, Monreal D, Peschke A. Marginal Quality of Class II Composite Restorations Placed in Bulk Compared to an Incremental Technique: Evaluation with SEM and Stereomicroscope. J Adhes Dent. 2015;17(2):147-54.

13. de Assis FS, Lima SNL, Tonetto MR, Bhandi SH, Pinto SCS, Malaquias P, et al. Evaluation of Bond Strength, Marginal Integrity, and Fracture Strength of Bulk-vs Incrementally-filled Restorations. J Adhes Dent. 2016;18(4):317-23.

14. Cidreira Boaro LC, Pereira Lopes D, de Souza ASC, Nakano EL, Perez MDA, Pfeifer CS, et al. Clinical performance and chemical-physical properties of bulk fill composites resin -a systematic review and meta-analysis. Dent Mater. 2019;35(10):e249-64. doi:10.1016/j.dental.2019.07.007.

15. Canali GD, Ignácio SA, Rached RN, Souza EM. One-year clinical evaluation of bulk-fill flowable vs. regular nanofilled composite in non-carious cervical lesions. Clin Oral Investig. 2019;23(2):889 97. doi:10.1007/s00784-018-2509-8.

16. Ehlers V, Gran K, Callaway A, Azrak B, Ernst CP. One-year Clinical Performance of Flowable Bulk-fill Composite vs Conventional Compomer Restorations in Primary Molars. J Adhes Dent. 2019;21(3):247 54. doi:10.3290/j.jad.a42519. 
17. Astvaldsdottir A, Dagerhamn ], van Dijken JW, Naimi-Akbar A, Sandborgh-Englund G, Tranaeus S, et al. Longevity of posterior resin composite restorations in adults - A systematic review. ] Dent. 2015;43(8):934-54.

18. Dentsply. Surefil SDR [Internet]. [cited 2019]un 22]. Available from: http:/www.surefilsdrflow.com.

19. Bucuta S, Ilie N. Light transmittance and micro-mechanical properties of bulk fill vs. conventional resin based composites. Clin Oral Investig. 2014;18(8):1991-2000.

20. Kim E, Jung H, Hur B, Kwon H, Park K. Effect of resin thickness on the microhardness and optical properties of bulk-fill resin composites. Restor Dent Endod. 2015;40(2):128-35.

21. Ilie N, Keßler A, Durner ]. Influence of various irradiation processes on the mechanical properties and polymerisation kinetics of bulk-fill resin based composites. J Dent. 2013;41(8):695-702.

22. Alrahlah A, Silikas N, Watts DC. Post-cure depth of cure of bulk fill dental resin-composites. Dent Mater. 2014;30(2):149-54.

23. Furness A, Tadros MY, Looney SW, Rueggeberg FA. Effect of bulk/incremental fill on internal gap formation of bulk-fill composites. J Dent. 2014;42(4):439-49.

24. Roggendorf M], Krämer N, Appelt A, Naumann M, Frankenberger R. Marginal quality of flowable 4-mm base vs. Conventionally layered resin composite. ] Dent. 2011;39(10):643-7.

25. Rosatto CMP, Bicalho AA, Veríssimo C, Bragança GF, Rodrigues MP, Tantbirojn D, et al. Mechanical properties, shrinkage stress, cuspal strain and fracture resistance of molars restored with bulk-fill composites and incremental filling technique. ] Dent. 2015;43(12):1519-28.

26. Leprince ]C, Palin WM, Vanacker ], Sabbagh ], Devaux ], Leloup G. Physico-mechanical characteristics of commercially available bulk-fill composites. ] Dent. 2014;42(8):993-1000.

27. Tantbirojn D, Pfeifer CS, Braga RR, Versluis A. Do low-shrink composites reduce polymerization shrinkage effects? J Dent Res. 2011;90(5):596-601.

28. van Dijken JWV, Pallesen U. Posterior bulk-filled resin composite restorations: A 5-year randomized controlled clinical study. J Dent. 2016;51:29-35

29. van Dijken JWV, Pallesen U. Bulk-filled posterior resin restorations based on stress-decreasing resin technology: a randomized, controlled 6-year evaluation. Eur] Oral Sci. 2017;125(4):303-9. doi:10.1111/eos.12351.

30. Demarco FF, Corrêa MB, Cenci MS, Moraes RR, Opdam NJM. Longevity of posterior composite restorations: Not only a matter of materials. Dent Mater. 2012;28(1):87-101.

31. Opdam N], Bronkhorst EM, Roeters JM, Loomans BA. Longevity and reasons for failure of sandwich and total-etch posterior composite resin restorations. J Adhes Dent. 2007;9(5):469-75.

32. Frascino S, Fagundes TC, Silva U, Rahal V, Barboza ACS, Santos PH, et al. Randomized Prospective Clinical Trial of Class II Restorations Using Low-shrinkage Flowable Resin Composite. Oper Dent. 2020;45(1):19 29. doi:10.2341/ 18-230-C.

33. Demunck], Van Landuyt K, Peumans M, Poitevin A, Lambrechts P, Braem M, et al. A critical review of the durability of adhesion to tooth tissue: methods and results. J Esthet Restor Dent. 2010;84(2):72-3.

34. Loguercio AD, Rezende M, Gutierrez MF, Costa TF, Armas-Vega A, Reis A. Randomized 36-month follow-up of posterior bulk-filled resin composite restorations. ] Dent. 2019;85:93 102. doi:10.1016/j.jdent.2019.05.018.

35. Correia A, Jurema A, Andrade MR, Borges A, Bresciani E, Caneppele T. Clinical evaluation of noncarious cervical lesions of different extensions restored with bulk-fill or conventional resin composite: preliminary results of a randomized clinical trial. Oper Dent. 2020;45(1):E11 E2O. doi:10.2341/18-256-C.

36. Yazici AR, Antonson SA, KutukZB, Ergin E. Thirty-Six-Month Clinical Comparison of Bulk Fill and Nanofill Composite Restorations. Oper Dent. 2017;42(5):478 85. doi:10.2341/16-220-C.

37. Sahadi BO, Price RB, André CB, Sebold M, Bermejo GN, Palma-Dibb RP, et al. Multiple-peak and single-peak dental curing lights comparison on the wear resistance of bulk-fill composites. Braz Oral Res. 2018;32:e122. doi:10.1590/1807-3107bor-2018.vol32.0122.

38. Shimokawa CAK, Turbino ML, Giannini M, Braga RR, Price RB. Effect of light curing units on the polymerization of bulk fill resin-based composites. Dent Mater. 2018;34(8):1211 21. doi:10.1016/j.dental.2018.05.002.

39. Soto-Montero ], Nima G, Rueggeberg FA, Dias C, Giannini M. Influence of Multiple Peak Light-emitting-diode Curing Unit Beam Homogenization Tips on Microhardness of Resin Composites. Oper Dent. 2020;45(3):327 38. doi:10.2341/19-027-L.

40. André CB, Nima G, Sebold M, Giannini M, Price RB. Stability of the Light Output, Oral Cavity Tip Accessibility in Posterior Region and Emission Spectrum of Light-Curing Units. Oper Dent. 2018;43(4):398 407. doi:10.2341/17-033-L.

41. Kim RJ, Son SA, Hwang JY, Lee IB, Seo DG. Comparison of photopolymerization temperature increases in internal and external positions of composite and tooth cavities in real time: Incremental fillings of microhybrid composite vs. bulk filling of bulk fill composite. ] Dent. 2015;43(9):1093-8. doi:10.1016/j.jdent.2015.07.003. 